\title{
Building bridges with book club Supporting international students' comfort and belonging on campus
}

A n evolving issue that many universities ace is the challenge of a welcoming and comfortable campus climate for international students. Host to more than 1 million students in 2018, the United States remains the top destination of international students globally. ${ }^{1}$ Many foreign students go to large institutions, but increasingly students from China, India, Saudi Arabia, and other countries enroll at smaller institutions or satellite campuses of state schools. More than $40 \%$ of international students studying in the United States in 2018 were at baccalaureate degree granting institutions. ${ }^{2}$

At a small campus such as Penn StateBrandywine, and as is likely the case at many other institutions, international students spend time with a cohort of students from their native countries. This may help alleviate the stress of communication in a second language, depression from being away from home, and other anxieties common to being in a new country. ${ }^{3}$ It is in the best interest of the university to make these students feel welcome among all their peers. To do that, students should feel comfortable taking advantage of the resources the university or campus offers, including participation in clubs, intramural sports, and social activities. It is also in the best interest of libraries to help students feel comfortable on the campus. Students who stay in their peer groups may not ask for assistance nor know that libraries and librarians can help with issues they may face.

How can libraries help to get these students intermingling, and thus, help students learn important information literacy skills?

\section{Book club collaboration}

In the spring semester of 2019, trying to answer the question of student engagement provided a unique opportunity for the Penn StateBrandywine librarians. Since 2016 there has been a student-led book club on campus. This club was started after Penn State-Brandywine librarians held a summer book club using Kindles to support audiobook listeners as well as book readers.

A write-up of the first iteration of Brandywine's Book Club was published in CERL News in May 2018, titled "Summer book club-a collaborative achievement: Using tech, time, and resources to engage students effectively." "While the first version of Brandywine book club used Kindles, each semester since has seen readers use a mix of ebooks, books, and audiobooks. Brandywine librarians have supported and participated in the club since its inception. The Brandywine Book Club meets once a month to discuss a book chosen by students. The conversation is very fluid and relaxed, though the club includes students, faculty, and staff. Most books previously selected are Young Adult genre fiction, including recent best selling novels by John Green, Angie Thomas, and Jason Reynolds. The club meetings are marketed through flyers posted around campus, tables set up at the involvement fairs each semester, and

Annie Jansen is reference and instruction librarian at Penn State-Brandywine, email: amj53@psu.edu

(c) 2019 Annie Jansen 
display tables in the library with copies of each title available for any interested parties. When an instructor in the Brandywine Multilingual Course Cluster saw the advertisements for book club, she approached the library with an idea to connect leisure reading with international student support and comfort.

Each spring semester, a comparative literature course within the Multilingual Course Cluster is offered. The students in this course cluster are international students or students who speak a language other than English at home. This course cluster is meant to engender comfort with the academic classroom, and though students enjoy it, it also means that many of these students remain in peer groups from their cohort in many of their classes at Brandywine.

The idea this past semester was to require participation in a book club meeting from each student in the comparative literature class. This would allow students to read a book in English that typical American students might enjoy, participate in a leisurely conversation about the content of the book, and see what a club meeting is like on campus. Students had the choice of signing up for one of four book club meetings during the spring semester, with no more than five students from the class allowed to come to each meeting. The library provided copies of each book for students to check out for the semester, and a librarian continued to participate in each book club meeting along with the comparative literature instructor.

\section{Increased cultural awareness for domestic and international students}

The immediate results of the collaboration were as expected. More students came to each meeting. The international students sat together in the club meetings. The domestic students who had participated in book club previously got the conversations started. The international students were happy to talk when pulled into the conversation by the librarian, their instructor, or another faculty or staff member at the meeting, but did not often volunteer their opinions.

What was most interesting in book club meetings with international student participation was the difference in topics that came up in discussion. When we discussed Thirteen Reasons Why by Jay Asher, a controversial book because of its depiction of teen suicide, Chinese students related the pressures of school and getting into a good university as the top stressors in their lives, while the domestic students mentioned work life balance or relationship troubles as stressors. The conversation from there did not lag, as students were eager to talk about their own lives and learn about their counterparts experiences, too.

When we discussed Buried Beneath the Baobab Tree by Adaobi Tricia Nwaubani, which is a fictionalized narrative of true accounts from young women kidnapped by Boko Haram in Nigeria, the American students did not immediately recall the news reports of the event, though it was widespread on social media. They were shocked that it happened and expressed outrage at the injustice. Conversely, some of the international students did not want to talk about the kidnapping in the novel because of the similarity to events their own families had faced in their native countries.

The differences in perspectives on the events in each book was enlightening to the students involved, as well as the instructor and librarian who participated in the club meetings. Even more interesting, and important to take into account when focusing on creating a sense of comfort and belonging for students on campus, were some of the small things the students in the comparative literature class shared with their instructor. Each student was required to hand in a short reflection on their experience in book club. They were asked to touch on what other students said in the meeting that surprised them, what they personally said during the meeting and how it was responded to, and whether the book club was a positive or negative experience for that student. Students overwhelmingly found the book club to be a positive experience and expressed surprise by the reactions to their comments during the club meetings. The students, it seems, did not have a preconceived notion of what a book club meeting might be like. The book club discussions this semester often ran off topic, 
into differences between cultures or languages, or a short lesson on something in American history or culture that the international students knew very little about. Sometimes the domestic students had not thought about these topics, either, or at the very least needed a refresher on. In many of the reflection statements from the comparative literature class, the difference between the meandering discussion in book club versus the regimented staying on task in their classrooms was commented on. As hoped, this kind of relaxed atmosphere helped the international students ease into social situations with students outside their cohort.

\section{Increased use of library services by international students}

The library has also seen benefits from this semester-long collaboration. International students, after having participated in the book club, have come into the library to browse the popular titles collection. Some have requested titles they want to read, including the Crazy Rich Asian trilogy and a recently published book by Malala Yousafzai. Students later in the semester made research appointments with librarians, seemingly because they now know a familiar face and some of the help that librarians can give. These small encounters have helped the library, and with it, the campus, to begin to create a welcoming atmosphere with for students who may face different sources of stress and anxiety than their American peers.

While the semester-long trial was a success and it will be implemented again in spring semester 2020, there are a few changes that will be made in coming semesters. The librarian will come to the comparative literature course classroom at the beginning of the semester to talk about checking books out of the library. The student reflection will also change slightly to include recommendations from students of titles they would like to read for book club.

The book club successfully acquainted international students not only to the pleasure of participating in student clubs on campus, but also served as an introduction to the services provided by an academic library. Though participation in book club originated as a way to engage international students with low pressure socialization, it also aligned directly with the Standards for Univesity Library Services to Undergraduate Students, specifically that the library "provide a gateway to all future library inquiry ... [including] teaching [undergraduate students] to use information sources as citizens, as consumers, as professionals, and for recreational purposes." 5 Starting with introducing the library as a place to get recreational reading allowed students to access library services without the pressure of an assignment. The semester showed that given that starting point, students are ready to dive in deeper to academic library services once they reach a level of comfort and belonging with the space, the staff, and their own information seeking needs.

\section{Notes}

1. Open Doors Report on International Educational Exchange, "Fall 2018 International Student Enrollment Hot Topics Survey," Institute of International Education, November 2018, accessed May 5, 2019, https://www.iie.org/Research-and-Insights /Open-Doors/Data/Fall-International -Enrollments-Snapshot-Reports.

2. Open Doors Report on International Educational Exchange, "Leading Host Institutions," Institute of International Education, November 2018, accessed May 7, 2019, https://www.iie.org/en/Research-and -Insights/Open-Doors/Data/International -Students/Leading-Host-Institutions.

3. Helen Gao, "Chinese, Studying in America, and Struggling, The New York Times, December 12, 2017, accessed May 15, 2019, https://www. nytimes.com/2017/12/12/opinion/chinesestudents-mental-health.html.

4. Annie Jansen, "Summer book club-a collaborative achievement: Using tech, time, and resources to engage students effectively," CERL News 79, no. 5 (2018): 257-60, https://doi. org/10.5860/crln.79.5.257.

5. "Guidelines for University Library Services to Undergraduate Students," ACRL, September 1, 2006, accessed May 9, 2019, www.ala.org/acrl /standards/ulsundergraduate. $\approx$ 